\title{
DIAGNOSIS, ASSESSMENT OF SEVERITY AND MANAGEMENT OF ACUTE PANCREATITIS
}

\author{
Suetlana Ignjatovićn ${ }^{1}$, Nada Majkić-Singh ${ }^{1}$, \\ Dejan Radenković2, Miomir Guozdenović2, Mihajlo Mitrović2 \\ IInstitute of Medical Biochemistry, Clinical Centre of Serbia and School of Pharmacy, \\ University of Belgrade, Belgrade, Serbia and Montenegro \\ ${ }^{2}$ Center for Urgent Surgery, Clinical Centre of Serbia and School of Medicine, \\ University of Belgrade, Belgrade, Serbia and Montenegro
}

\begin{abstract}
Summary: Severe pancreatitis occurs in $20 \%-30 \%$ of all patients with acute pancreatitis. Pancreatic enzymes, cytokines and other active peptides, liberated from the inflamed pancreas, convert inflammation of the pancreas as a single-organ disease of the retroperitoneum to a multisystem disease. Determinations of pancreatic serum enzymes are still »the golden standard « for diagnosis of the acute pancreatitis. Out of clinically significant pancreatic enzymes, pancreatic-amylase and lipase are suggested for routine clinical determination due to available methods for their measurement. The methods are simple, and the results may be obtained rather quickly without any special equipment. Maximal diagnostic accuracy is achieved by »cut-off « values of $182 \mathrm{U} / \mathrm{L}$ for pancreatic-amylase and $656 \mathrm{U} / \mathrm{L}$ for lipase. Treatment of patients with acute pancreatitis is based on the initial assessment of disease severity. Early staging is based on the presence and degree of systemic failure (cardiovascular, pulmonary, and renal) and on the presence and extent of pancreatic necrosis. Individual clinical parameters and laboratory biomarkers, although sometimes helpful, are not sufficiently accurate to reliable assess the severity of an acute attack. Numeric grading systems with sensitivities of about $70 \%$ are commonly used today as indicators of organ failure and disease severity. Contrast material-enhanced computed tomography is used in addition to help evaluate local pancreatic morphology and the presence and extent of pancreatic necrosis. Out of all recently studied biochemical parameters for prognostic evaluation of acute pancreatitis patients, the measurement of $\mathrm{C}$-reactive protein concentration appeared to be the parameter with the highest clinical accuracy. The best differentiation of moderate from severe acute pancreatitis forms is achieved by "cut-off « CRP values of $126 \mathrm{mg} / \mathrm{L}$, 48 hours from the onset of symptoms. For this reason, CRP measurement may be used as the alternative to computerized tomography. In compliance with the postulations for evidence-based medicine, the procedures related to diagnosis, prognosis and management of acute pancreatitis are classified into four categories: certain, probable, possible and inappropriate.
\end{abstract}

Key words: acute pancreatitis, diagnosis, prognosis, management, evidence-based medicine

\section{Introduction}

In the majority of cases, acute pancreatitis is a mild and self-limiting disease, with an uneventful recovery of the patient and a mortality of less than $2 \%$. Nevertheless, $20 \%-30 \%$ of all patients develop severe disease, characterized by the occurrence of systemic complications and a $20 \%-30 \%$ risk of fatal

Address for correspondence:

Svetlana Ignjatović

Institute of Medical Biochemistry

Clinical Centre of Serbia \& University School of Pharmacy

Višegradska 26, 11129 Belgrade, Serbia \& Montenegro

e-mail: tana@eunet.yu outcome. In recent years, research in the field of acute pancreatitis has almost exclusively focused on this subgroup of severely ill patients. Although this has led to considerable progress in the treatment of acute pancreatitis, systemic complications remain a therapeutic challenge and a main prognostic determinant of the disease (1-5).

The diagnosis, early assessment, and management of severe acute pancreatitis remain difficult clinical problems. This article presents the consensus obtained at a meeting convened to consider the evidence in these areas. The aim of the article is to provide outcome statements to guide clinical practice, with an assessment of the supporting evidence for 
each statement. A careful assessment was made of the strength of the available evidence (certain, probable, possible and inappropriate) (6-7).

\section{Definition of acute pancreatitis}

In 1992, a new clinically oriented classification system for acute pancreatitis was developed (8). Severe acute pancreatitis was defined by the presence of organ failure or local complications, especially pancreatic necrosis. Precise definitions were provided for organ failure and pancreatic necrosis. The so-called Atlanta classification recognizes both the pathomorphologic and the clinical characteristics of severe acute pancreatitis. According to this definition, severe acute pancreatitis is associated with systemic complications, such as organ failure and/or local complications, such as necrosis, abscess, or pseudocyst. Although the Atlanta system discriminates between local and systemic complications of the disease, there is, apparently, a close connection between these entities, as it is a common observation that systemic complications are almost exclusively restricted to patients with pancreatic necrosis (9-11).

\section{Clinical and laboratory diagnosis of acute pancreatitis}

There are disease-specific signs or symptoms and the diagnosis of acute pancreatitis requires a synthesis of clinical, laboratory, and imaging-procedure finding (2). Determination of serum pancreatic enzymes remains the "gold standard « for the diagnosis of acute pancreatitis. Clinical symptoms and signs are of major importance in suspecting the disease, but they are not accurate enough to confirm the diagnosis. A further aspect in the diagnosis of acute pancreatitis is the identification of the etiological factor (12).

In the past, measurement of numerous serum markers has been recommended for diagnosis of acute pancreatitis. Among these, nearly all pancreatic secretory enzymes such $\alpha$-amylase (EC 3.2.1.1), lipase (EC 3.1.1.3), trypsin (EC 3.4.21.4), elastase (EC 3.4.21.36), ribonuclease (EC 3.1.27.5), phospholipase $\mathrm{A}_{2}$ (EC 3.1.1.4), and carboxypeptidase B (EC 3.4.17.2) can be found (13-19). For only a small number of enzymatic markers, however, was sufficient data available to appreciate their value for diagnosis of pancreatic diseases (20). Out of clinically significant pancreatic enzymes, pancreatic $\alpha$-amylase and lipase are suggested for routine clinical determination due to available methods for their measurement. The methods are simple, and the results may be obtained rather quickly without any special equipment. Maximal diagnostic accuracy is achieved by »cut-off « values of $182 \mathrm{U} / \mathrm{L}$ for pancreatic $\alpha$-amylase and $656 \mathrm{U} / \mathrm{L}$ for lipase (21-24). To early define the etiology of acute pancreatic serum pancreatic enzymes lack of value (25).
The development of acute pancreatitis occurs in $4-8 \%$ of patients with symptomatic gallstones. Individuals predisposed to acute pancreatitis tend to have small gallstones (with or without larger gallstones), a wide cystic duct and a common channel between the biliary and pancreatic ducts. The importance of this relationship is demonstrated by the ability of urgent endoscopic sphincterotomy (ES) to improve the outcome of a predicted severe attack and to virtually abolish recurrent attacks in patients who are unable to undergo cholecystectomy. Biliary crystals are an important marker of microlithiasis or a propensity to form further gallstones following their passage into the duodenum following an attack. A combination of ultrasonography and a serum liver transaminase of $>60 \mathrm{U} / \mathrm{L}$ ( $<48$ hours on an attack) are necessary to provide optimum sensitivity and specificity for gallstones as a prompt for the use of ERCP (endoscopic retrograde cholangiopancreatography) and ES in severe cases. Biliary sludge as a cause of acute pancreatitis is not proven. Twenty five to thirty percent of patients will develop complications with a mortality of around 8\%. Urgent diagnosis of gallstones and treatment by ES can result in substantial improvement in outcome (26).

\section{Prognosis of acute pancreatitis}

Even though the diagnosis of pancreatitis has become easier by the measurement of specific pancreatic enzymes there are still $30 \%-40 \%$ of the fatal cases which are first diagnosed at autopsy. It is of utmost importance to assess the diagnosis and the severity of acute pancreatitis in the beginning to identify those patients with severe or necrotising disease who benefit from an early initiated intensive care therapy. Additionally, in view of new therapeutical concepts (e.g. antibiotic therapy in severe forms) and for the evaluation of new drugs, patients should be staged into mild and severe disease as early as possible. In most cases it is not possible to assess the severity clinically on hospital admission. Up to now the »gold standard « are imaging procedures (contrast-enhanced (T) which should be reserved for the severe cases to estimate the extent of pancreatic necrosis (27).

The ideal predictor in blood or in urine should be objective, reliable, inexpensive, and easy to measure, widely available, sensitive and specific. There are varieties of mediators of the "systemic inflammatory response syndrome « which are elevated in this disease: C-reactive protein (CRP), antiproteases, enzyme activation peptides like trypsinogen activation peptide and carboxypeptidase B activation peptide, PMNelastase, complement factors, chemokines and interleukins and others. Phospholipase $\mathrm{A}_{2}$ and pancreatitis-associated protein, which are produced and liberated during the initial phase of pancreatic damage, have been confrmed as good early markers of seve- 
rity. However, their clinical application is inappropriate at present. Trypsinogen activation peptide and carboxypeptidase B show great promise as markers of severity, but further development is required before their assay can be useful clinically.

Among all these mediators, C-reactive protein is the parameter best analyzed. It has to be taken into account that it is not specific for acute pancreatitis and its highest efficacy is reached after $>48$ hours after the onset of disease. However, because usually a certain time elapses (approximately 24-48 hours) until patients are hospitalized the time delay seems not to a major disadvantage (28-32). Assay of CRP is only easely available blood test in clinical practice that is a proven discriminator of severe and mild disease at »cut-off « level of $126 \mathrm{mg} / \mathrm{L}$ at 48 hours after the onset of symptoms. For this reason, CRP measurement may be used as the alternative to computerized tomography $(6,33)$.

\section{Management of patients with acute pancreatitis}

Management of patients with acute pancreatitis is based on the early assessment of severity of disease. As clinical examination in the first 24 hours after admission is unreliable in predicting a serious attack of acute pancreatitis, much efforts has been made to develop combination of criteria that might better predict severity. Ranson et al. (34) in 1974 introduced a combination of different clinical signs and laboratory markers as a scoring system in this disease. In the meantime, various other clinical scores have been employed for patients with acute pancreatitis. Among these, the Acute Physiology and Chronic Health Evaluation (APACHE) II score and the Glasgow criteria have been most carefully evaluated (35-37). Although scoring systems are useful, to some extent, in the identification of patients with severe acute pancreatitis, their sensitivity and specificity is limited to $70 \%$. If a multifactor system is to be used, APACHE II score calculated at 24 hours has proven to be the best choice. Obesity, indicated by a body mass index greater than 30 , is a reasonably reliable predictor of severe outcome, especially if it used along with APACHE II score (6). Another major drawback of most scoring systems is that daily evaluation is necessary, and that it takes 3 to 4 days to achieve a reliable prediction of severity. A considerable percentage of patients develop complications despite scores having been low during the initial course. Although scoring systems are widely used in patients with acute pancreatitis, they are of only limited use in the prediction of severe attacks. This explains why a recent audit on the management of acute pancreatitis revealed that only a minority of hospitals perform severity stratification of patients within the first hours by using scores (38). The major rationale for scoring in acute pancreatitis today is the comparability of patients participating in clinical trials.

CT staging and the CT severity index have proved to be a reliable indicator of disease severity, having shown an excellent correlation with the risk of death and the development of local and systemic complications in this population (1).

Acute pancreatitis is a disease with a variety of symptoms. In patients in whom the disease takes a more severe course, stabilization is mandatory, often in a high dependency unit or intensive care unit. Aggressive organ support and continuation of the prophylactic antibiotics are the mainstay of treatment. When infected necrosis has been proven by CT-guided fine needle biopsy, surgical necrotectomy and debridement with drainage are necessary. Enteral feeding is superior to parenteral feeding even in situations of severe pancreatitis. Further investigation into the role of selective digestive tract decontamination, by controlled randomized trials, is needed (39-41).

\section{Conclusions}

There is reliable evidence to support much current practice. Clear guidance can be given in most areas examined, and several areas were identified where further investigation would be helpful. Diagnosis using plasma concentrations of pancreatic enzymes is reliable. Rapid advances are taking place in the assessment of severity. Several new therapeutic strategies show real promise for the reduction of morbidity and mortality rates. Surgical debridement is required for infected pancreatic necrosis, but is less often necessary for sterile necrosis $(1,6)$.

Acute pancreatitis is a potentially fatal disease, with reported mortality rates ranging from zero to almost 25 per cent, depending on severity and holds out several areas for future investigation through randomized trials. In particular, answers are required to settle controversies surrounding use of antibiotics and enteral nutrition. The time is ripe for a re-evaluation of the indications for surgery and of operative techniques. 


\title{
DIJAGNOZA, PROCENA TEŽINE I MENADŽMENT AKUTNOG PANKREATITISA
}

\author{
Suetlana Ignjatović ${ }^{1}$, Nada Majkić-Singh ${ }^{1}$, \\ Dejan Radenković2, Miomir Guozdenović ${ }^{2}$, Mihajlo Mitrović2 \\ ${ }^{1}$ Institut za medicinsku biohemiju, Klinički centar Srbije i Farmaceutski fakultet \\ Univerziteta u Beogradu, Beograd, Srbija i Crna Gora \\ 2Urgentni centar, Klinički centar Srbije i Medicinski fakultet Univerziteta u Beogradu, \\ Beograd, Srbija i Crna Gora
}

\begin{abstract}
Kratak sadržaj: Težak oblik bolesti se javlja kod 20\%-30\% pacijenata sa akutnim pankreatitisom. Oslobađanje pankreasnih enzima, citokina i drugih aktivnih peptide iz pankreasa zahvaćenog inflamacijom uzrokuje prelaz od zapaljenja jednog organa u retroperitoneumu ka multisistemskom oboljenju. Određivanje pankreasnih enzima u serumu još uvek ostaje »zlatan standard« u dijagnozi akutnog pankreatitisa. Od klinički važnih pankreasnih enzima za kliničko rutinsko određivanje preporučuju se pankreasna $\alpha$-amilaza i lipaza zbog postojanja raspoloživih metoda za njihovo određivanje. Metode su jednostavne, rezultat može da se dobije dosta brzo i ne zahteva posebnu opremu za određivanje. Maksimalna dijagnostička tačnost se postiže pri "cut-off « vrednostima od $182 \mathrm{U} / \mathrm{L}$ za pankreasnu $\alpha$-amilazu i $656 \mathrm{U} / \mathrm{L}$ za lipazu. Tretman pacijenata sa akutnim pankreatitisom se zasniva na inicijalnoj proceni težine oboljenja. Rana gradacija se zasniva na prisustvu i stepenu sistemskih oštećenja (kardiovasdkularnih, pulmonalnih i renalnih), kao i na prisustvu i veličini pankreasne nekroze. Mada individualni klinički parametri i laboratorijski biomarkeri mogu da budu od pomoći, to nije dovoljno tačno u proceni težine napada. Brojni "sistemi scorova « koriste se danas kao indikatori oštećenja organa i težine oboljenja i njihova osetljivost iznosi oko $70 \%$. Kompjuterizovana tomografija poboljšana kontrastom se koristi za dodatnu evaluaciju lokalne pankreasne morfologije, kao i stepena pankreasne nekroze. Od svih do sada ispitivanih biohemijskih parametara za prognostičku evaluaciju pacijenata sa akutnim pankreatitisom, određivanje koncentracije C-reaktivnog proteina (CRP) predstavlja parametar sa najvećom kliničkom tačnošću. Najbolje razlikovanje blagih od teških oblika AP se postiže pri »cut-off « vrednosti CRP od $126 \mathrm{mg} / \mathrm{L}$ i to 48 sati od početka simptoma. Iz ovih razloga određivanje CRP može da se koristi kao alternativa kompjuterizovanoj tomografiji. U skladu sa postulatima na kojima se zasniva medicina zasnovana na dokazima (eng. evidence-based medicine) postupci vezani za prognozu i tretman akutnog pankreatitisa se klasifikuju u četiri kategorije: izvesni, verovatni, mogući i neodgovarajući.
\end{abstract}

Ključne reči: akutni pancreatitis, dijagnoza, prognoza, menadžment, medicina zasnovana na dokazima

\section{References}

1. Beger HG, Bettina R, Isenmann R. Prevention of severe change in acute pancreatitis: prediction and prevention. J Hepatobiliary Pancreat Surg 2001; 8: 140-7.

2. Beger HG, Rau B, Mayer J, Prall U. Natural course of acute pancreatitis. World J Surg 1997; 21: 130-5.

3. Beger HG, Isenmann R. Surgical management of necrotizing pancreatitis. Surg Clin North Am 1999; 79: $783-800$.

4. Tsiotos GG, Luque-de Leon E, Söreide JA, Bannon MP, Zietlow SP, Baerga-Varela Y, Sarr MG. Management of necrotizing pancreatitis by repeated operative necrosectomy using a zipper technique. Am J Surg 1998; 175: 91-8.

5. Bradley ELI, Allen K. A prospective longitudinal study of observation versus surgical intervention in the management of necrotizing pancreatitis. Am J Surg 1991; 161: 19-25.

6. Dervenis C, Bassi C. Evidence-based assessment of severity and management of acute pancreatitis. $\mathrm{Br} \mathrm{J}$ Surg 2000; 87: 257-8.
7. Dervenis C, Johnson CD, Bradley E, Imrie CW, McMahon MJ, Modlin I. Diagnosis, objective assessment of severity, and management of acute pancreatitis - Santorini consensus conference. Int J Pancreatol 1999; 25/3: 195-210.

8. Bradley EL. A clinically based classification system for acute pancreatitis. Summary of the International Symposium on Acute Pancreatitis, Atlanta, GA, September 11-13, 1992. Arch Surg 1993; 128: 586-90.

9. Balthazar EJ, Robinson DL, Megibow AJ, Ranson JC. Acute pancreatitis: value of CT in establishing prognosis. Radiology 1990; 174: 331-6.

10. Gerzof SG, Banks PA, Robbins AH, Johnson WC, Spechler SJ, Wetzner SM, Snider JM, Langevin RE, Jay $M E$. Early diagnosis of pancreatic infection by computed tomographyguided aspiration. Gastroenterology 1987; 93: 1315-20.

11. Widdison AL, Karanjia ND. Pancreatic infection complicating acute pancreatitis. Br J Surg 1993; 80: 148-154.

12. Kazmierczak SC, Catrou PG, Van Lente F. Enzymatic markers of gallstone-induced pancreatitis identified by ROC curve analysis, discriminant analysis, logistic re- 
gression, likelihood ratios, and information theory. Clin Chem 1995; 41/4: 523-31.

13. Elman A, Arneson N, Graham EA. Value of blood amylase estimations in the diagnosis of pancreatic disease: a clinical study. Arch Surg 1929; 19: 943-67.

14. Warshaw AL, Lee KH. Serum ribonuclease elevations and pancreatic necrosis in acute pancreatitis. Surgery 1979; 86: 227-34.

15. Nordback I, Teerenhovi O, Auvinen O, Koivula T, Thuren $T$, Kinnunen $P$, et al. Human pancreatic phospholipase A2 in acute necrotising pancreatitis. Digestion 1989; 42: 128-34.

16. Büchler $M$, Malfertheiner $P$, Schädlich $H$, Nevalainen TJ, Friess H, Beger HG. Role of phospholipase A2 in human acute pancreatitis. Gastroenterology 1989; 97: 1521-6.

17. Agarwal N, Pitchumoni CS, Sivaprasad AV. Evaluating tests for acute pancreatitis. Am J Gastroenterol 1990; 85: 356-66.

18. Benini L, Bevilacqua D, Brocco G, Pilati S, Bardelli E, Vantini I, Cavallini G. Lipase latex test for acute abdominal pain: comparison with serum lipase, trypsin, elastase and amylase. Ital J Gastroenterol 1992; 24: 61-4.

19. Bennini L, Rizotto P, Vaona B, Sembenini C, Brocco G, Micciolo R, et al. Elastase 1 vers trypsin, lipase, amylase serum levels in pancreatic diseases. Int $\mathrm{J}$ Pancreatol 1987; 2: 361-70.

20. Agarwal N, Pitchumoni CS, Sivaprasad AV. Evaluating tests for acute pancreatitis. Am J Gastroenterol 1990; 5: 356-66.

21. Ignjatović S, Todorović M, Gvozdenović M, Mirković D. Sensitivity and specificity of different plasma enzyme assays in the diagnosis of acute pancreatitis. In: List WF, Muller MM, McQueen MJ, eds. Advances in critical care testing - the 1996 IFCC-AVL award, Springer-Verlag, Berlin, 1997; 161-2.

22. Ignjatović S, Majkić-Singh N, Mitrović M, Gvozdenović $M$, Todorović $M$. Lipase, total and pancreatic amylases as markers of acute pancreatitis identified by ROC curve analysis. European Journal of Laboratory Medicine 1997; 5/3: 1-3.

23. Panteghini $M$, Ceriotti F, Pagani F, Secchiero S, Zaniotto $M$, Franzini $C$. recommendations for the routine use of pancreatic amylase measurement instead of total amylase for the diagnosis and monitoring of pancreatic pathology. Clin Chem Lab Med 2002; 40/2: 97-100.

24. Moridani MY, Bromberg IL. Lipase and pancreatic amylase versus total amylase as biomarkers of pancreatitis: an analytical investigation. Clin Biochem 2003; 36: 31-3.

25. Kazmierczak SC, Catrou PG, Van Lente F. Diagnostic accuracy of pancreatic enzymes evaluated by use of multivariate data analysis. Clin Chem 1993; 39: 1960 - 5.

26. Liu C-L, Lo C-m, Fan S-T. Acute biliary pancreatitis: diagnosis and management. World J Surg 1997; 21: 149-54.
27. Malfertheiner P, Dominguez-Munoz JE. Prognostic factors in acute pancreatitis. Int $\mathrm{J}$ Pancreatology 1993; 14 (1): $1-8$.

28. Mayer J, Rau B, Gansauge F, Beger HG. Inflammatory mediators in human acute pancreatitis: clinical and pathophysiological implications. Gut 2000; 47: 546-52.

29. Gudgeon AM, Heath DI, Hurley P, Jehanli A, Patel G, Wilson C, et al. Trypsinogen activation peptides assay in the early prediction of severity of acute pancreatitis. Lancet 1990; 335: 4-8.

30. Kemppainen EA, Hedstrom JI, Puolakkainen PA, et al. Rapid measurement of urinary trypsinogen-2 as a screening test for acute pancreatitis. N Engl J Med 1997; 336: $1788-93$.

31. Müller CA, Appelros S, Uhl W, Büchler MW, BorgstrÎm A. Serum levels of procarboxypeptidase $B$ and its activation peptide in patients with acute pancreatitis and non-pancreatic diseases. Gut 2002; 51: 229-35.

32. Viedma JA, Perez-Mateo M, Dominguez JE, Carballo F. Role of interleukin- 6 in acute pancreatitis. Comparison with C-reactive protein and phospholipase A. Gut 1992; 33: $1264-7$

33. Ignjatović S, Majkić-Singh $\mathrm{N}$, Mitrović $M$, Gvozdenović $M$. Biochemical evaluation of patients with acute pancreatitis. Clin Chem Lab Med 2000; 38 (11): 1141-4.

34. Ranson JC, Rifkind KM, Roses DF, Fink SD, Eng K, Spencer FC. Prognostic signs and the role of operative management in acute pancreatitis. Surg Gynecol Obstet 1974; 139: 69-81.

35. Larvin M, McMahon M. APACHE-II score for the assessment and monitoring of acute pancreatitis. Lancet 1989; 2: 201-5.

36. Fan S, Lai ECS, Mok F, Lo C, Zheng S, Wong J. Prediction of the severity of acute pancreatitis. Am J Surg 1993; 166: 262-9.

37. Wilson C, Heath DI, Imrie CW. Prediction of outcome in acute pancreatitis: a comparative study of APACHE II, clinical assessment and multiple factor scoring systems. Br J Surg 1990; 77: 1260-4.

38. Toh SK, Phillips S, Johnson CD. A prospective audit against national standards of the presentation and management of acute pancreatitis in the south of England. Gut 2000; 46: 139-243.

39. Stoupis Ch, Becker Ch, Vock P, Uhl W, Buchler MW. Imaging procedures in acute pancreatitis. Dig Surg 1994; 11: 209-13.

40. Balthazar EJ. Staging of acute pancreatitis. Radiol Clin North Am. 2002; 40 (6): 1199-209.

41. Balthazar EJ. Complications of acute pancreatitis: clinical and CT evaluation. Radiol Clin North Am. 2002; 40 (6): 1211-27. 